\title{
Scenario-based economic and societal risk assessment of storm flooding in Shanghai
}

\author{
Jin Tang and Weijiang Li
}

School of Environmental and Geographical Sciences, Shanghai Normal University, Shanghai, China

Jiayi Fang

School of Geographic Sciences, East China Normal University, Shanghai, China

Zhonghao Zhang and Shiqiang $\mathrm{Du}$

School of Environmental and Geographical Sciences, Shanghai Normal University, Shanghai, China

\section{Yanjuan $\mathrm{Wu}$}

Department of Geography and Spatial Information Techniques, Ningbo University, Ningbo, China, and

Jiahong Wen

School of Environmental and Geographical Sciences, Shanghai Normal University, Shanghai, China

\begin{abstract}
Purpose - Quantitative and spatial-explicit flood risk information is of great importance for strengthening climate change adaptation and flood resilience. Shanghai is a coastal megacity at large estuary delta with rising flood risks. This study aims to quantify the overall economic-societal risks of storm flooding and their spatial patterns in Shanghai.

Design/methodology/approach - Based on multiple storm flood scenarios at different return periods, as well as fine-scale data sets including gridded GDP, gridded population and vector land-use, a probabilistic risk model incorporating geographic information system is used to assess the economic-societal risks of flooding and their spatial distributions.
\end{abstract}

(c) Jin Tang, Weijiang Li, Jiayi Fang, Zhonghao Zhang, Shiqiang Du, Yanjuan Wu and Jiahong Wen. Published by Emerald Publishing Limited. This article is published under the Creative Commons Attribution (CC BY 4.0) licence. Anyone may reproduce, distribute, translate and create derivative works of this article (for both commercial and non-commercial purposes), subject to full attribution to the original publication and authors. The full terms of this licence may be seen at http:// creativecommons.org/licences/by/4.0/legalcode

This work was supported by the National Natural Science Foundation of China (Grants No. 41771540, 4187010049, 42001014), the National Key Research and Development Program of China (Grant No. 2017YFC1503001), the Humanity and Social Science Youth Foundation of Ministry of Education of China (Grant No. 20YJCZH180), the Zhejiang Public Welfare Technology Research Project (Grant No. LGF21D010003), the Basic Science and Technology Project of Ningbo (Grant No. 202002N3200), and the Ningbo Fan-3315 Plan.

Disclosure statement: No potential conflict of interest was reported by the author(s).

Societal risk assessment

Received 5 June 2021 Revised 10 July 2021 28 July 2021 
IJCCSM

$13,4 / 5$

Findings - Our results show that, from 1/200 to 1/5,000-year floods, the exposed assets will increase from USD 85.4bn to USD 657.6bn, and the direct economic losses will increase from USD 3.06bn to USD 52bn. The expected annual damage (EAD) of assets is around USD $84.36 \mathrm{~m}$. Hotpots of EAD are mainly distributed in the city center, the depressions along the upper Huangpu River in the southwest, the north coast of Hangzhou Bay, and the confluence of the Huangpu River and Yangtze River in the northeast. From 1/200 to 1/5,000-year floods, the exposed population will rise from 280 thousand to 2,420 thousand, and the estimated casualties will rise from 299 to 1,045. The expected annual casualties (EAC) are around 2.28. Hotspots of casualties are generally consistent with those of EAD.

Originality/value - In contrast to previous studies that focus on a single flood scenario or a particular type of flood exposure/risk in Shanghai, the findings contribute to an understanding of overall flood risks and their spatial patterns, which have significant implications for cost-benefit analysis of flood resilience strategies.

Keywords Shanghai, Economic and societal risk, Scenario-based probabilistic risk model, Storm flooding

Paper type Research paper

\section{Introduction}

Cities located in coastal lowlands and estuarine deltas are growing and expanding much faster than in other areas (Seto et al., 2011). Driven by climatic and non-climatic factors such as sea level rise, ground subsidence and rapid growth of population and asset, coastal cities are facing rising flood risks (Arnell and Gosling, 2014; Chan et al., 2018; Fang and Shi, 2019; Tauzer et al., 2019). Flooding associated with extreme storm surges is among the most costly and deadly hazards in densely populated and economically developed coastal cities (Cook and Merwade, 2009). Storm flooding or storm-surge flooding, occurs when wind and low pressure combine at the center of a storm, which pulls up water and carry it inland. Storm flooding has become a significant concern in the risk assessment of coastal cities (Dube et al., 2009; Peduzzi et al., 2012). Quantitative and spatially explicit flood economic-societal risk information is of great importance for coastal cities to strengthen climate change adaptation and flood resilience (Hinkel et al., 2018; Jongman, 2018; White et al., 2018; Fang et al., 2020).

Climate change is expected to make storm flooding more destructive in the coming decades(Lin et al., 2012; Irish et al., 2014; Marsooli and Lin, 2020). First, rising sea levels will raise the baseline elevations of waves and storm surges as thermal expansion and melting ice caps continue. A small vertical rise in sea level will translate into a very large increase in horizontal reach by storm surge, and thus will exacerbate the frequency and severity of storm flooding (Hunter et al., 2013; Wu et al., 2017; Rasmussen et al., 2018). Studies show that global mean sea level has been rising since the last century due to global warming and is projected to reach 1 meter or more by the end of the 21st century (Dasgupta et al., 2009; Rahmstorf, 2017; Grinsted and Christensen, 2021). Second, a warmer ocean will intensify tropical storm activity and heighten storm surges. Continued sea-surface warming will lead to more intense tropical storms with higher peak wind speeds and heavier precipitation (Webster et al., 2005; IPCC, 2007; Emanuel et al., 2008; Knutson et al., 2010; Bhatia et al., 2018). IPCC (2007) cites a trend toward longer duration and greater intensity of storms since the mid-1970s, and a strong correlation with the upward trend in tropical sea surface temperatures. As storm surges increase under climate change, they will create more devastating flood conditions in coastal areas and adjacent low-lying areas, with more population and assets at risk. Therefore, it is essential for coastal cities to focus on risk assessment and management of storm flooding under climate change.

The economic risk can be expressed by the amount of money likely to be lost as a consequence of flooding (Winsemius et al., 2013). Previous studies usually calculate the 
direct economic losses based on either GDP aggregated by administrative divisions (Winsemius et al., 2013; Ward et al., 2014), or land values of different land use categories (Jonkman et al., 2008; Merz et al., 2010; Hanson et al., 2011; Jongman et al., 2012; Yin et al., 2012b; Du et al., 2020), which is not sufficient to describe the heterogeneity of risks in detail. With the development of spatial disaggregation methods, more gridded GDP data sets are available recently. Based on the gridded GDP data, the distribution of high-resolution asset value can be derived to support spatially explicit flood economic exposure and loss analysis (Peduzzi et al., 2009; Winsemius et al., 2013; Wu et al., 2018).

The societal risk can be expressed by the potential fatality or injury to a group of individuals induced by hazards such as flooding (Jonkman and Vrijling, 2008; Maaskant et al., 2009; de Bruijn et al., 2014). Quantitative assessment of flood casualties has been widely conducted in developed countries (FitzGerald et al., 2010; Di Mauro et al., 2012; Sharif et al., 2015; Qiang, 2019), while it is rarely done in developing countries, typically due to the lack of up-to-date and spatialized census data (Paul and Mahmood, 2016). Currently, open and accessible gridded population data in developing countries make it possible to assess flood casualties and their spatial patterns (Di Mauro et al., 2012; Luu et al., 2017).

Shanghai is considered to be the most vulnerable city to storm flooding among the nine deltaic coastal cities worldwide (Balica et al., 2012). It also ranks as one of the top 20 cities in the world in terms of population exposure and property exposure to floods (Hallegatte $e$ t al., 2013). Compound flooding of extreme rainstorm, astronomical high tide, storm surge and upstream flood is one of the catastrophic hazards in Shanghai (Wang et al., 2012). Previous studies on food risks in Shanghai include flood hazard simulation and mapping (Wang et al., 2012; Yin et al., 2013; Wang et al., 2019), damage to residential buildings and household properties (Ke, 2014; Shan et al., 2019), direct and indirect losses of industrial networks (Huang et al., 2017; Li et al., 2019) and flood adaptation measures in Shanghai (Du et al., 2020). However, these studies only focus on a single flood scenario or a certain type of flood exposure, which is insufficient for understanding the overall flood risks and their spatial patterns in Shanghai.

Therefore, based on multiple storm flood scenarios in different return periods, as well as fine-scale data sets including gridded GDP, gridded population and vector land-use, we use a probabilistic risk model incorporating geographic information system (GIS) to quantify the economic-societal risks of flooding in Shanghai and their spatial patterns. Our findings can provide fundamental risk information for decision-making on flood resilience strategies.

\section{Data and methods}

\subsection{Study area}

Shanghai is located in the eastern edge of the Yangtze River Delta, with a total area of $6,340.5 \mathrm{~km}^{2}$ (Figure 1). In 2018, the density of residential population in Shanghai exceeds 3,823 persons $/ \mathrm{km}^{2}$, and the total GDP approaches USD $0.51 \mathrm{tn}$ with a density of USD $80.5 \mathrm{~m} /$ $\mathrm{km}^{2}$. High densities of population and assets exposed to flooding are typical features of disaster risks in Shanghai.

Shanghai lies in a flat and low-lying coastal region with an average altitude of $4.0 \mathrm{~m}$. It is surrounded by water on three sides, with the estuary of the Yangtze River to the north, the East China Sea to the east and the Hangzhou Bay to the south. The Huangpu River flows through the metropolitan area. Shanghai is frequently threatened by storm surge, storm flooding and torrential rainfall brought by typhoon. For instance, in 1905, storm flooding caused nearly 30 thousand casualties in Shanghai (Yuan, 1999). In 1962, storm flooding inundated half of the downtown area for nearly 10 days due to 46 failures along the floodwalls of the Huangpu River and its branches and led to huge losses of $1 / 6$ of the total 
IJCCSM

$13,4 / 5$

\section{2}

Figure 1.

Study area

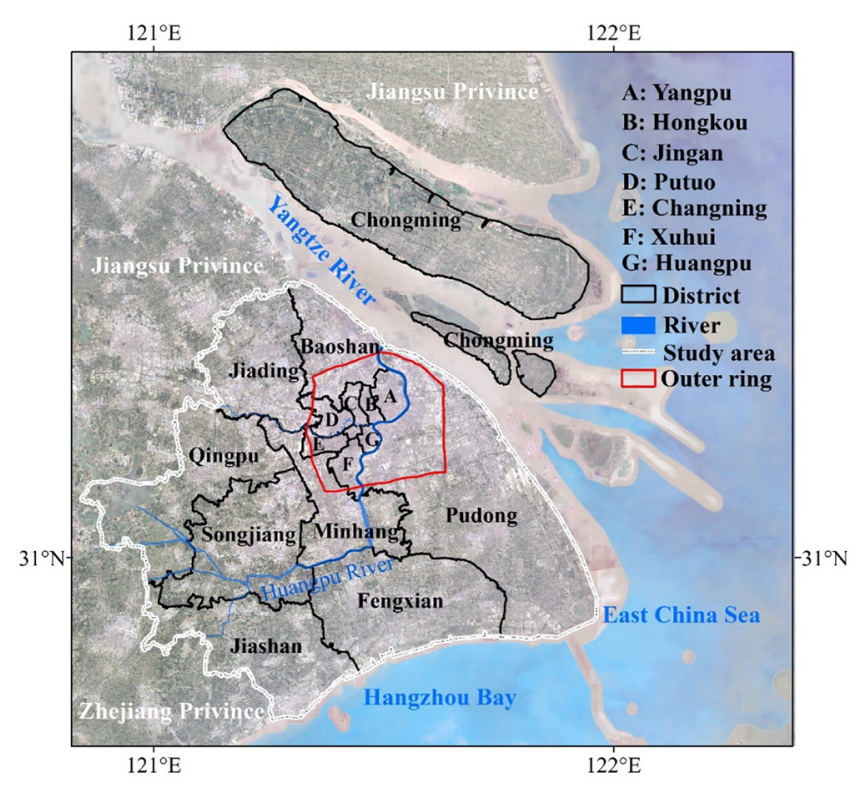

GDP in Shanghai (Yin et al., 2012a; Ke, 2014). Storm surges during typhoon 9711 raised the water level of the Huangpu River to $5.72 \mathrm{~m}$, the highest record till now, at the Huangpu Park where the flood almost overtopped the floodwall. Shanghai suffers from typhoons around 1.5 times per year and the resulting annual flood frequency has increased significantly since 1949 (Du et al., 2015). In the future, with sea level rise and ground subsidence in Shanghai, the return periods of storm flooding will be shortened remarkably (Wang et al., 2018; Yin et al., 2020).

\subsection{Data}

The data sets used in this study include the storm flood scenarios simulated in four return periods (i.e. $1 / 200,1 / 500,1 / 1,000$ and 1/5,000-year), the $1-\mathrm{km}$ gridded GDP data in 2015, the100-m gridded population data in 2015, the vector land-use data in 2015, the annual GDP data and the fixed asset investment data in Shanghai from 1978 to 2017.

The storm flood inundation scenarios are simulated and mapped by our group (Wang et al., 2019). It is required by China's State Council that some downtown sections of the Huangpu River in Shanghai should meet the protection standard of a 1/1000-year flood(Ke, 2014; Micheal et al., 2019). Thus, based on the historical monitoring data, the extreme water levels (EWLs) in the four return periods are calculated using the extreme value distribution function(Ke, 2014; Ke et al., 2018). As boundary conditions, the EWLs in the four return periods are input to an integrated numerical modeling system to simulate the inundation processes of storm floods, respectively. The numerical modeling system is coupled with the atmospheric model (Fujita typhoon model), ocean model (TELEMAC tide model with TOMAWAC wave model) and coastal model (MIKE $1 \mathrm{D} / 2 \mathrm{D}$ hydrodynamic model). With the numerical modeling system, the storm flood inundation scenarios in the four return periods are simulated including inundation parameters such as extent and depth, and the corresponding flood maps are created. The flood maps in this study exclude the Chongming 
District (consisting of Chongming Island, Changxing Island and Hengsha Island) due to the lack of boundary conditions of the water level in different return periods.

The gridded GDP data in 2015 are obtained from the China National Earth System Science Data Center (http://www.geodata.cn), which are generated from the county-level GDP statistics using a spatial disaggregation model.

The gridded population data in 2015 are derived from Harvard Dataverse, which are produced by the Worldpop program (Gaughan et al., 2016) and available at http://www. Worldpop.org.uk. The spatialized data are generated from the county-level census data using random forest and density partitioning mapping techniques.

The vector land-use data in 2015 are manually interpreted from remote sensing images and classified as categories of agriculture, residence, industry and warehouse, transportation, public service and other (including under construction, special and unused lands).

The annual nominal GDP data as well as the fixed asset investment data from 1978 to 2017 are acquired from the Shanghai Statistical Yearbook 2018.

\subsection{Framework and methods}

2.3.1 Research framework. Risk can be quantitatively expressed by the set of triplet $\left(S_{i}, P_{i}\right.$, $C_{i}$ ) (Kaplan and Garrick, 1981), where, $S_{i}$ denotes the $i^{t h}$ scenario, $P_{i}$ refers to the probability of the $i^{t h}$ scenario, and $C_{i}$ means the losses of the $i^{t h}$ scenario. This risk consists of hazard scenarios, losses and probabilities, so it is the scenario-based probabilistic risk. As such, flood risk can be understood as the probability of floods with given intensity and the potential losses in a specific region and within a given time span. If flood scenarios are ordered in terms of the severity of potential losses, a risk curve can be plotted to indicate the relationship between potential losses and annual exceedance probability (AEP) scenarios. In addition, with GIS applied, risk can be displayed as maps of potential losses in various AEP scenarios (Li et al., 2016).

Following the scenario-based probabilistic risk model, the research framework is shown in Figure 2. First, the asset value and its spatial distribution are estimated based on the gridded GDP data. Then, the exposed assets and population are identified by overlaying the

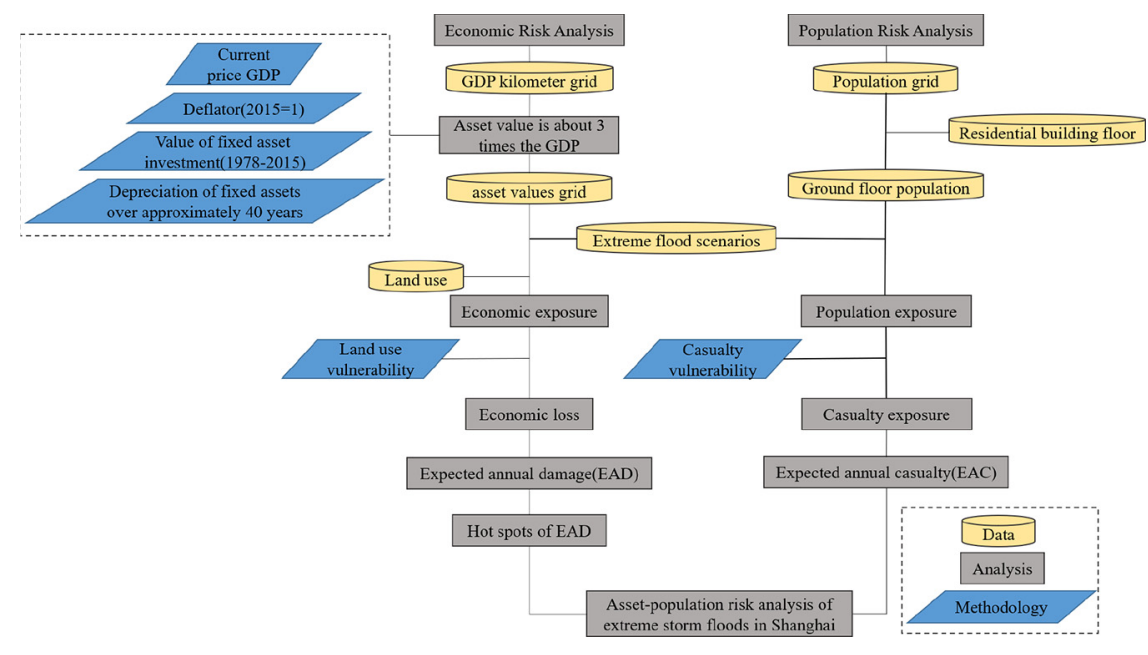

\section{grided}


IJCCSM

$13,4 / 5$

\section{4}

gridded asset data, the gridded population data, and the storm flood scenarios at different return periods. Next, asset damages and population casualties under different flood scenarios are estimated using vulnerability curves. Afterwards, the risk curve is plotted to calculate the expected annual damages $(\mathrm{EAD})$ of assets and the expected annual casualties (EAC) of population. Finally, spatial patterns and hot spots of the flood risks in Shanghai are identified using GIS.

\subsubsection{Flood economic risk assessment}

(1) Assessing the asset value and its spatial distribution:

Following the methods by Nicholls et al. (2008), asset value and its spatial distribution are estimated with the gridded GDP data. The annual GDP data and fixed asset investment data from 1978 to 2017 are firstly normalized to 2017 prices.

Given that the average useful life of fixed asset is around 40 years (Nicholls et al., 2008), the net asset value (V) in 2015 is calculated as in equation (1):

$$
\mathrm{V}_{2015}=\sum_{i=1978}^{2015} v_{i}
$$

where, $v_{i}$ represents the net asset value after depreciation in the $i^{\text {th }}$ year.

The coefficient (M) between the net asset value and GDP in 2015 is computed using equation (2):

$$
\mathrm{M}=\frac{V_{2015}}{G D P_{2015}}
$$

With the computed coefficient M $(\approx 3)$, the gridded asset value in 2015 is derived from the gridded GDP data.

(2) Assessing the asset damages and economic risk:

By overlaying the gridded flood map, gridded asset value map and vector land-use map, grids with inundation depth, asset value and land-use attributes are obtained.

With the flood depth-damage curves for seven land-use categories in Shanghai (Yin et al., 2012a), the asset damages are estimated as in equation (3):

$$
\mathrm{AD}=\sum_{j=1}^{7} \sum_{i=1}^{n}\left(E_{i j} \times F_{j}\right)
$$

where, $E_{i j}$ refers to the asset value of the $i^{\text {th }}$ grid within the $j^{\text {th }}$ land-use category, $F_{i}$ represents the damage ratio of the $j^{\text {th }}$ land-use category, and AD denotes the asset damages.

After calculating the asset damages in the four return periods, the damage-AEP curve is plotted to indicate the relationship between the annual flood exceedance probability and the asset damages and is further used to calculate the expected annual damage (EAD). The EAD can be expressed as equation (4) (Ward et al., 2011):

$$
\mathrm{EAD}=\int x f(x) d(x)
$$

where, $x$ refers to the occurrence probability of a flood with a given intensity, i.e. AEP. $f(x)$ refers to the asset damages of the flood with $x$. 
(3) Identifying the hot spots of economic risk:

The spatial autocorrelation analysis $\left(\mathrm{G}_{\mathrm{i}}^{*}\right.$ index) is performed to identify the hot and cold assessment spots of the EAD at the neighborhood scale (Getis and Ord, 1992).

$$
\mathrm{G}_{\mathrm{i}}^{*}=\frac{\sum_{j=1}^{n} w_{i j}(d) x_{j}}{\sum_{j=1}^{n} x_{j}}
$$

where, $w_{i j}$ is an n-by-n symmetrical matrix of 0 and 1 representing the spatial relationship between neighborhood $i$ and all other neighborhoods, and $x_{i}$ and $x_{j}$ refer to the risk values of neighborhood $i$ and $j$, respectively.

\subsubsection{Flood societal risk assessment.}

(1) Assessing the population exposure

The average number of building floors in Shanghai is around 6 (Shan et al., 2019). Assuming that the population is evenly distributed among the six floors, the population on the ground floor is computed in equation (6):

$$
\mathrm{P}=\frac{p o p}{6}
$$

where, $p o p$ is the total population in each grid, and $\mathrm{P}$ is the estimated ground population in each grid.

According to the flood maps created in the study, the areas with inundation depth greater than $3 \mathrm{~m}$ (exceeding the average height of the ground floor) cover less than $0.05 \%$ of the total flooded areas under the four flood scenarios. Thus, only the population on the ground floor is considered to be at flood risk. By overlaying the gridded ground population map and the flood inundation map, the exposed population and its spatial distribution are calculated.

(2) Assessing the casualties and societal risk:

The population casualties are estimated using the depth-casualty function by Boyd et al. (2005), which is fitted from the post-flood survey data.

$$
\mathrm{F}(h)=\frac{0.34}{(1+\exp (20.37-6.18 h))}
$$

where, $h$ represents the inundation depth. $\mathrm{F}(h)$ is the casualty ratio.

After estimating the flood casualties in the four return periods, the casualty-AEP curve is plotted to show the societal risk to flooding and thus used to calculate the EAC.

\section{Results}

\subsection{Asset exposure}

Figure 3 displays the spatial patterns of assets exposed to flooding. As the intensity of flooding increases, the exposed assets expand from small dispersed areas to large continuous areas. Under the 1/5,000-year flood scenario, the density of the exposed asset value exceeds USD $500 / \mathrm{m}^{2}$ in the city center and USD $100 / \mathrm{m}^{2}$ in the east coast of Pudong 


\section{IJCCSM \\ $13,4 / 5$}

\section{6}

Figure 3.

Spatial distribution of exposed assets under the four flood scenarios in Shanghai

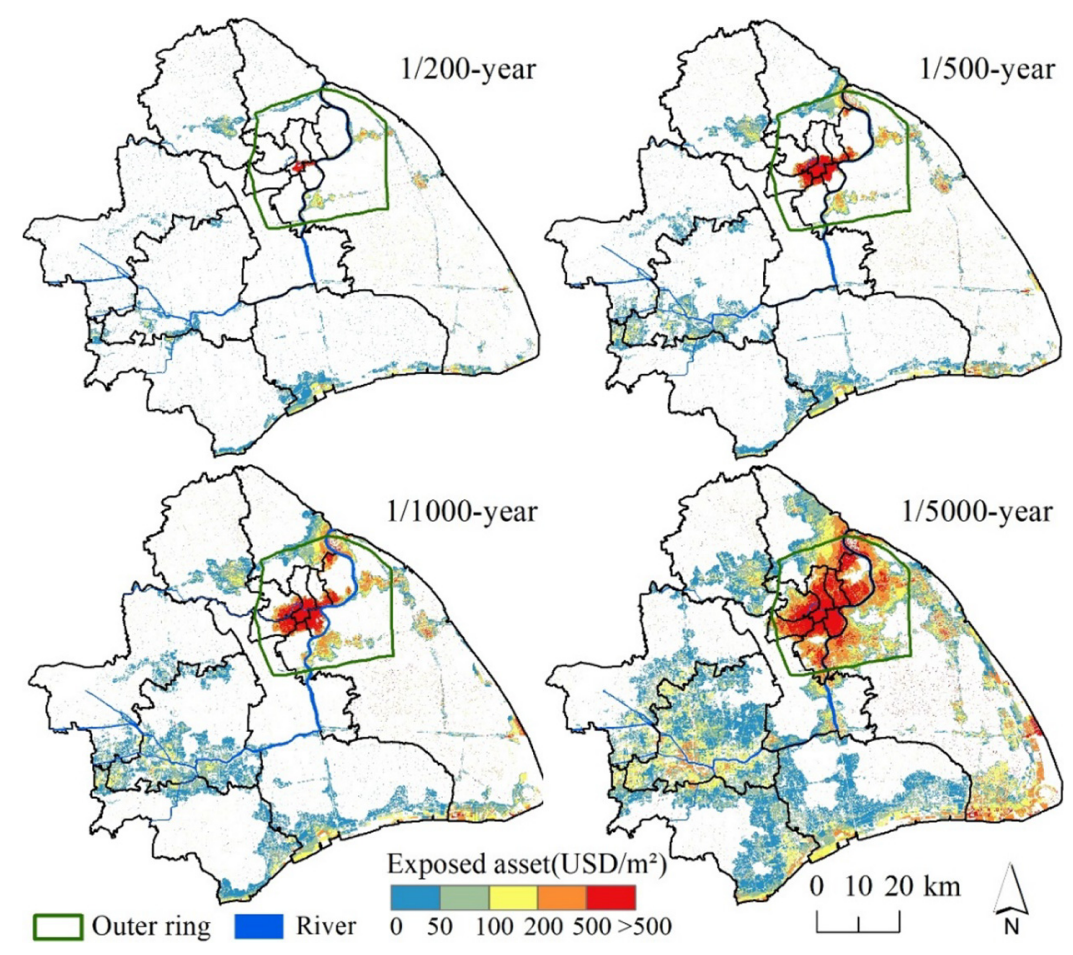

District. In contrast, the density of the exposed asset value in the western and southern areas is relatively low.

Table 1 summarizes the exposed assets based on land-use categories. Under the four flood scenarios, residential land has the largest share of the exposed assets, followed by public service land, transportation land, industrial and warehouse land.

\subsection{Asset losses and economic risk}

3.2.1 Asset losses. The asset losses under the four flood scenarios are estimated with equation (3) (Figure 4). Under the 1/200-year flood scenario, the asset losses are approximately USD 3.06bn, with densities typically below USD $20 / \mathrm{m}^{2}$. Under the $1 / 5,000$ year flood scenario, the asset losses are as high as USD 52bn, with densities over USD $20 / \mathrm{m}^{2}$ in the city center and over USD $10 / \mathrm{m}^{2}$ in the north coast of the Hangzhou Bay and the upstream of the Huangpu River.

\begin{tabular}{lrrrrrrr}
\hline $\begin{array}{l}\text { Flood } \\
\text { return } \\
\text { periods }\end{array}$ & Residence & $\begin{array}{c}\text { Public } \\
\text { service }\end{array}$ & Transportation & \multicolumn{1}{c}{$\begin{array}{c}\text { Industry and } \\
\text { warehouse }\end{array}$} & Agriculture & Other & \multicolumn{1}{c}{ Total } \\
\hline $1 / 200$ & $24.6(28.8 \%)$ & $20.7(24.3 \%)$ & $13.7(16.0 \%)$ & $14.8(17.3 \%)$ & $9.8(11.5 \%)$ & $1.8(2.1 \%)$ & $85.4(100 \%)$ \\
$1 / 500$ & $79.3(33.9 \%)$ & $60.6(25.9 \%)$ & $43.1(18.5 \%)$ & $28.8(12.3 \%)$ & $18.0(7.7 \%)$ & $3.9(1.7 \%)$ & $233.7(100 \%)$ \\
$1 / 1,000$ & $113.2(34.1 \%)$ & $83.1(25.0 \%)$ & $58.3(17.5 \%)$ & $44.0(13.3 \%)$ & $26.2(7.9 \%)$ & $7.3(2.2 \%)$ & $332.1(100 \%)$ \\
$1 / 5,000$ & $214.3(32.6 \%)$ & $154.9(23.6 \%)$ & $111.0(16.9 \%)$ & $105.5(16.0 \%)$ & $57.3(8.7 \%)$ & $14.6(2.2 \%)$ & $657.6(100 \%)$ \\
\hline
\end{tabular}

\section{Table 1.}

Exposed assets (unit: billion USD) and their proportions (unit: \%) based on land-use categories 


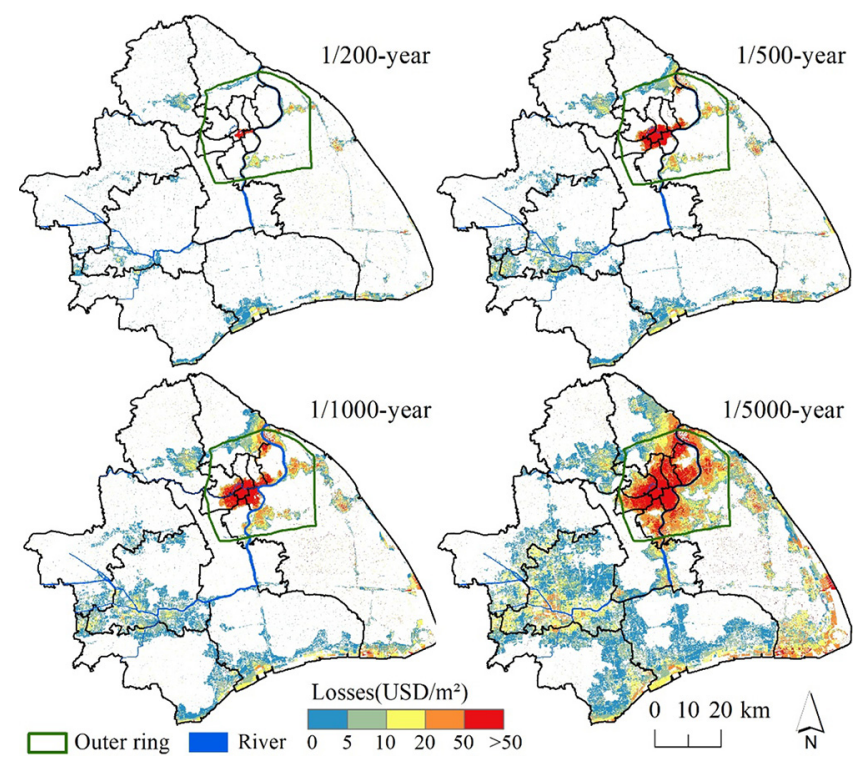

Table 2 lists the asset losses in different land-use categories. Residential, public service and agricultural lands rank the top three in asset losses, accounting for $28.3 \%, 19.2 \%$ and $30.8 \%$ of the total losses under the 1/200-year flood scenario, and $41.1 \%, 22.0 \%$ and $20.3 \%$ of the total losses under the 1/5,000-year flood scenario, respectively.

3.2.2 Economic risk curve. The economic risk curve is plotted based on the asset losses under the four flood scenarios (Figure 5).

Using equation (4), the EAD of total assets are estimated to be USD $84.36 \mathrm{~m}$, among which $41.8 \%, 23.1 \%$ and $19.1 \%$ are in residential, public service and agricultural lands, respectively, (Table 3).

3.2.3 Hotspot analysis of economic risk. The hot and cold spots of the EAD in Shanghai are obtained at the neighborhood scale using equation (5) (Figure 6). Several hot spots are identified in the city center, in the depressions along the upper Huangpu River in the southwest, along the north coast of Hangzhou Bay, and at the confluence of the Huangpu River and Yangtze River in the northeast. The cold spots are mainly located around the hotspots in the city center.

\begin{tabular}{lccrcccc}
\hline $\begin{array}{l}\text { Flood } \\
\text { return }\end{array}$ & & \multicolumn{5}{c}{ Asset losses in different land-use categories } \\
periods & Residence & \multicolumn{1}{c}{$\begin{array}{c}\text { Public } \\
\text { service }\end{array}$} & \multicolumn{1}{c}{ Agriculture } & warehouse & Transportation & Other & Total \\
\hline $1 / 200$ & $0.87(28.3 \%)$ & $0.59(19.2 \%)$ & $0.94(30.8 \%)$ & $0.46(15.2 \%)$ & $0.14(4.5 \%)$ & $0.06(2.0 \%)$ & $3.06(100 \%)$ \\
$1 / 500$ & $6.18(43.6 \%)$ & $3.44(24.2 \%)$ & $2.41(17.0 \%)$ & $1.08(7.6 \%)$ & $0.93(6.6 \%)$ & $0.13(1.0 \%)$ & $14.17(100 \%)$ \\
$1 / 1,000$ & $9.78(43.5 \%)$ & $5.39(23.9 \%)$ & $3.89(17.3 \%)$ & $1.76(7.8 \%)$ & $1.44(6.4 \%)$ & $0.25(1.1 \%)$ & $22.51(100 \%)$ \\
$1 / 5,000$ & $21.38(41.1 \%)$ & $11.44(22.0 \%)$ & $10.53(20.3 \%)$ & $4.96(9.5 \%)$ & $3.07(5.9 \%)$ & $0.62(1.2 \%)$ & $52.00(100 \%)$
\end{tabular}

Societal risk assessment

537

Figure 4.

Spatial distribution of asset losses under four flood scenarios in Shanghai 
IJCCSM

$13,4 / 5$

538

Figure 5.

Flood damage-AEP

curve

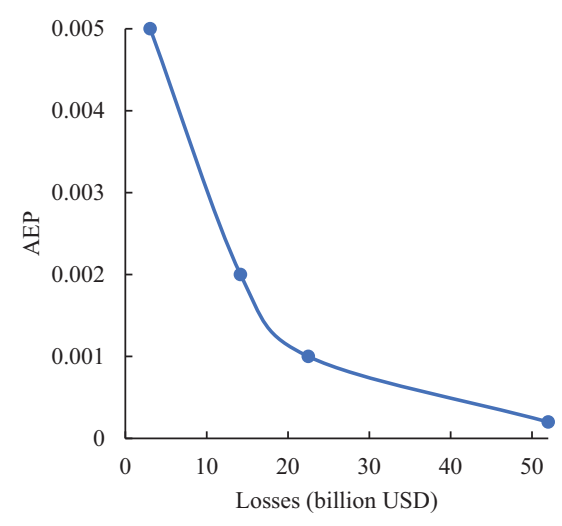

Table 3.

Expected annual damages of different land-use categories
Land-use categories EAD (million USD) Percentage $(\%)$

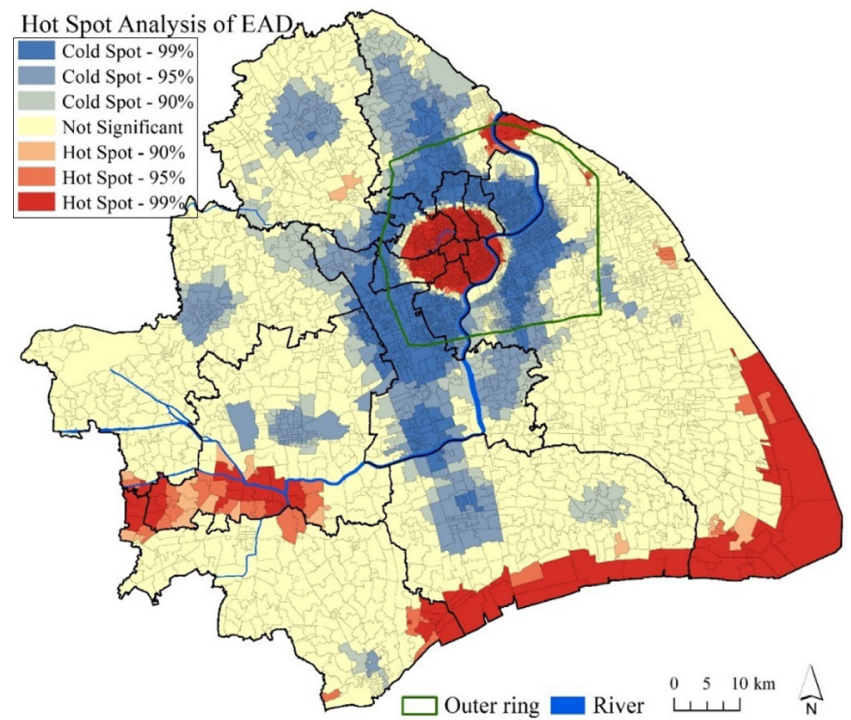

3.3 Population casualties and societal risk

The exposed population (Table 4) and its spatial distribution (Figure 7) under the four flood scenarios are calculated from equation (6). The exposed population also shows a significant upward trend with rising flood intensity. Under the 1/200-year flood scenario, the exposed
Figure 6.

Hot and cold spots of EAD in Shanghai
Industry and

Residence Public service Agriculture warehouse Transportation Other Total

\begin{tabular}{lllllll}
35.29 & 19.50 & 16.10 & 7.43 & 5.11 & 0.93 & 84.36 \\
41.8 & 23.1 & 19.1 & 8.8 & 6.1 & 1.1 & 100 \\
\hline
\end{tabular}


population is 280 thousand, making up $1.2 \%$ of the total population in Shanghai. Under the 1/5,000-year flood scenario, the exposed population amounts to 2.42 million, approximately $10 \%$ of the total population in Shanghai, with a high density of over 2 thousand persons/ $\mathrm{km}^{2}$ in the city center.

The potential casualties of the population are estimated with equation (7) (Table 4). Under the 1/5,000-year flood scenario, the casualties are over 1,000, 3.5 times that under the 1/200-year flood scenario. Based on the casualties under the four flood scenarios (Table 4), the EAC are calculated to be 2.28 (Figure 8).

\section{Discussions}

\subsection{Uncertainties}

Several studies have been carried out to assess flood risks in Shanghai or other similar cities. For instance, Shan et al. (2019) examined the flood damage to residential buildings and household properties in Shanghai under the same flood scenarios. Our results of asset losses present similar pattern to those of Shan et al. (2019), but the losses in our study are significantly higher in the north coast of Hangzhou Bay mainly due to the use of more comprehensive asset values derived from the gridded GDP data. Under the same flood scenarios and with the land values of different land-use categories, Du et al. (2020) calculated the expected annual flood damages in Shanghai to be USD 106m (at 2015 prices), which is

\begin{tabular}{lcrrr}
\hline Flood return periods & Exposed population & Casualties & Table 4. \\
\cline { 1 - 2 } $1 / 200$ & 280,000 & 299 & Population exposure \\
$1 / 500$ & 730,000 & 378 & and casualties under \\
$1 / 1,000$ & $1,110,000$ & 495 & four flood scenarios \\
$1 / 5,000$ & $2,420,000$ & 1,045 & four \\
\hline
\end{tabular}

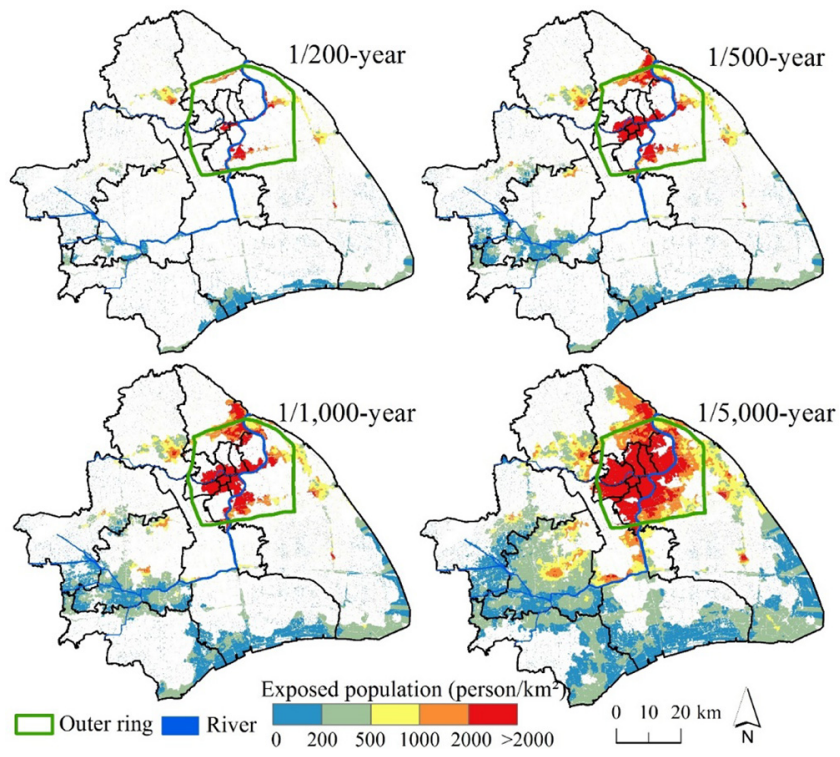

Figure 7.

Spatial distribution of exposed population under four flood scenarios in Shanghai 


\section{IJCCSM \\ $13,4 / 5$}

\section{0}

Figure 8.

Flood casualty - AEP curve

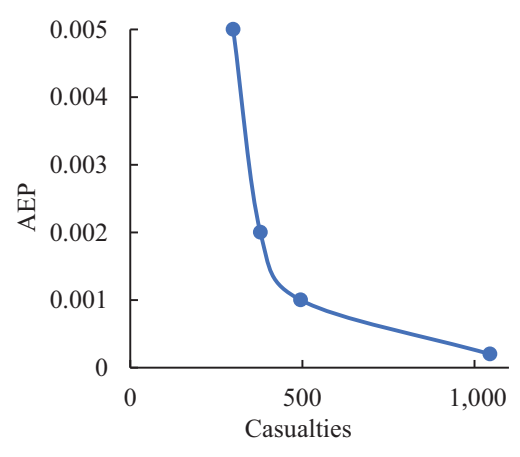

comparable to our results of USD 84.36m. Aerts et al. (2013) estimated the annual damages of low probability flooding in New York to be USD 59m-129m, which is also consistent with our results. The storm flooding during Hurricane Sandy in 2012, with a return period of 1/350- year (Lin et al., 2016), affected 8.4 million people and caused 43 casualties in New York. The Chao Phraya River flooding in 2011, with a return period of 1/50-year (Promchote et al., 2016), impacted 1.5 million people and induced 600 casualties in Thailand. Compared to the above studies and facts, the estimates on the asset losses and population casualties in this study are reasonable.

However, there are some uncertainties in our results, largely from the flood hazard modeling and the exposure and vulnerability analysis. First, various parameters are input into the integrated flood hazard simulation system (Wang et al., 2019), such as the land elevation, storm track and intensity, EWLs and local bathymetry. Different parameter settings can lead to variation and uncertainty in the simulation results. In particular, significant uncertainty may arise from the estimates of low-probability EWLs based on short-term observational data and extreme value distribution functions. Second, the gridded GDP and population data used for exposure analysis are developed from census data with spatial disaggregation methods. The census data are only available by census units, with uncertainties on how the data distribute spatially within each unit, thus causing uncertainties in the derived gridded GDP and population data. Third, a major source of uncertainty is the damage curve that describes the relationship between hazard parameters and the resulting relative/absolute damage for a certain type of element. Damage curve is highly variable according to the locations and time. As there are no government standards or recommendations on the flood damage assessment in Shanghai, the depth-damage curves for seven land-use categories of Yin et al. (2012a) and the depth-casualty function of Boyd et al. (2005) are used in this study. These curves should be further calibrated with more local damage data. In addition to inundation depth, other damageinfluencing factors such as inundation duration and velocity should be considered in the future.

\subsection{Research implications}

Quantifying and mapping the spatial patterns of disaster risks is one of the key tasks for risk assessment. In this study, we develop a methodology framework to assess the overall economic-societal risks of storm flooding in Shanghai using a probabilistic risk model incorporating GIS technology. Compared to previous studies that use aggregated data at administrative units, we derive spatially refined flood risk maps with open gridded GDP and population data. Moreover, based on the time series of gridded GDP and land-use data and the Shared Socioeconomic Pathways (SSPs), future spatial patterns of GDP and asset 
values can be projected. This will help to assess the non-climatic driving forces on future flood risks (Merkens et al., 2016; Jiang et al., 2018).

In this study, several hotspots with high flood risks are identified, where different resilience measures should be prioritized according to local conditions. For instance, in the city center with dense population and assets, both structural and natural-based measures are necessary, such as reinforcing floodwalls of the Huangpu River, upgrading urban drainage capacity with pumping stations and expanding the urban permeable surface. In the depressions along the upper Huangpu River with dense river networks, natural-based solutions are more appropriate. These measures include optimizing land-use patterns, restoring natural river networks and their roles in flood storage and regulation and reserving flow paths for excessive water in case of flooding. Along the coasts, structural measures remain the preferred options, two of which are constructing tidal barrier near the confluence of the Huangpu River and Yangtze River and upgrading seawalls. In addition, development in ecologically sensitive areas such as wetlands, mangroves and forests should be strictly regulated. Protecting ecologically sensitive areas is critical not only to environmental impact mitigation and conservation, but also to flood resilience enhancement. For instance, mangroves improve flood resilience through attenuating tidal waves and storm surges (Barbier, 2015).

\section{Conclusions}

Under climate change and sea level rise, the frequency and intensity of storm flooding is expected to increase. Driven by rapid urbanization, population and assets will continue to grow in coastal cities and face rising risks from storm flooding. Based on four storm flood scenarios with different return periods, as well as the gridded GDP data, gridded population data and vector land-use data, this paper explores the overall flood economic-societal risks and their spatial patterns in Shanghai. The main conclusions are as follows.

(1) From 1/200 to 1/5,000-year flood scenarios, the exposed assets increase from USD 85.4bn to USD 657.6bn, and the asset losses increase from USD 3.06bn to USD $52 \mathrm{bn}$. The EAD of assets is around USD $84.37 \mathrm{~m}$, with residential, public service and agricultural lands accounting for $41.8 \%, 23.1 \%$ and $19.1 \%$, respectively. The hotpots of the EAD are distributed in the city center, in the depressions along the upper Huangpu River in the southwest, along the north coast of Hangzhou Bay, and at the confluence of the Huangpu River and Yangtze River in the northeast.

(2) From 1/200 to 1/5,000-year flood scenarios, the exposed population rises from 280 thousand to 2.42 million, and the estimated casualties rise from 299 to 1,045. The EAC is around 2.28. The hotspots of the EAC are generally consistent with those of EAD.

(3) Our study provides quantitative and spatially explicit flood risk patterns in Shanghai, which has significant implications for cost-benefit analysis of climate change adaptation and flood resilience.

\section{References}

Aerts, J.C.J.H., Lin, N., Botzen, W., Emanuel, K. and de Moel, H. (2013), "Low-Probability flood risk modeling for New York city", Risk Analysis, Vol. 33 No. 5, pp. 772-788.

Arnell, N.W. and Gosling, S.N. (2014), "The impacts of climate change on river flood risk at the global scale”, Climatic Change, Vol. 134 No. 3, pp. 387-401. 
IJCCSM

$13,4 / 5$
Balica, S.F., Wright, N.G. and van der Meulen, F. (2012), “A flood vulnerability index for coastal cities and its use in assessing climate change impacts", Natural Hazards, Vol. 64 No. 1, pp. 73-105.

Barbier, E.B. (2015), "Climate change impacts on rural poverty in low-elevation coastal zones", Estuarine Coastal and Shelf Science, Vol. 165 No. 5, pp. 1-13.

Bhatia, K., Vecchi, G., Murakami, H., Underwood, S. and Kossin, J. (2018), "Projected response of tropical cyclone intensity and intensification in a global climate model", Journal of Climate, Vol. 31 No. 20, pp. 8281-8303.

Boyd, E., Levitan, M. and van Heerden, I. (2005), "Further specification of the dose-response relationship for flood fatality estimation", US-Bangladesh Workshop on Innovation in Windstorm/Storm Surge Mitigation Construction. National Science Foundation and Ministry of Disaster and Relief, Government of Bangladesh, Dhaka.

Chan, F.K.S., Chuah, C.J., Ziegler, A.D., Dąbrowski, M. and Varis, O. (2018), "Towards resilient flood risk management for Asian coastal cities: lessons learned from Hong Kong and Singapore", Journal of Cleaner Production, Vol. 187, pp. 576-589.

Cook, A. and Merwade, V. (2009), "Effect of topographic data, geometric configuration and modeling approach on flood inundation mapping", JOURNAL oF Hydrology, Vol. 377 Nos 1/2, pp. 131-142.

Dasgupta, S., Laplante, B., Meisner, C., Wheeler, D. and Yan, J. (2009), "The impact of sea level rise on developing countries: a comparative analysis", Climatic Change, Vol. 93 Nos 3/4, pp. 379-388.

de Bruijn, K.M., Diermanse, F.L.M. and Beckers, J.V.L. (2014), "An advanced method for flood risk analysis in river deltas, applied to societal flood fatality risk in The Netherlands", Natural Hazards and Earth System Sciences, Vol. 14 No. 10, pp. 2767-2781.

Di Mauro, M., De Bruijn, K.M. and Meloni, M. (2012), "Quantitative methods for estimating flood fatalities: towards the introduction of loss-of-life estimation in the assessment of flood risk", Natural Hazards, Vol. 63 No. 2, pp. 1083-1113.

Du, S., Gu, H., Wen, J., Chen, K. and Van Rompaey, A. (2015), "Detecting flood variations in shanghai over 1949-2009 with Mann-Kendall tests and a newspaper-based database”, Water, Vol. 7 No. 12, pp. 1808-1824.

Du, S., Scussolini, P., Ward, P.J., Zhang, M., Wen, J., Wang, L., Koks, E., Diaz-Loaiza, A., Gao, J., Ke, Q. and Aerts, J.C.J.H. (2020), "Hard or soft flood adaptation? Advantages of a hybrid strategy for shanghai", Global Environmental Change, Vol. 61, p. 102037.

Dube, S.K., Jain, I., Rao, A.D. and Murty, T.S. (2009), "Storm surge modelling for the Bay of Bengal and Arabian sea", Natural Hazards, Vol. 51 No. 1, pp. 3-27.

Emanuel, K., Sundararajan, R. and Williams, J. (2008), "Hurricanes and global warming: results from downscaling IPCC AR4 simulations", Bulletin of the American Meteorological Society, Vol. 89 No. 3, pp. 347-367.

Fang, J., Lincke, D., Brown, S., Nicholls, R.J., Wolff, C., Merkens, J.L., Hinkel, J., Vafeidis, A.T., Shi, P. and Liu, M. (2020), "Coastal flood risks in China through the 21st century - An application of DIVA", Science of the Total Environment, Vol. 704, p. 135311.

Fang, J. and Shi, P. (2019), "A review of coastal flood risk research under global climate change", Progress in Geography, Vol. 38 No. 5, pp. 625-636.

FitzGerald, G., Du, W., Jamal, A., Clark, M. and Hou, X.Y. (2010), "Flood fatalities in contemporary Australia (1997-2008)", Emergency Medicine Australasia : Ema, Vol. 22 No. 2, pp. 180-186.

Gaughan, A.E., Stevens, F.R., Huang, Z., Nieves, J.J., Sorichetta, A., Lai, S., Ye, X., Linard, C., Hornby, G. M., Hay, S.I., Yu, H. and Tatem, A.J. (2016), "Spatiotemporal patterns of population in mainland China, 1990 to 2010", Scientific Data, Vol. 3 No. 1, p. 160005. 
Getis, A. and Ord, J.K. (1992), "The analysis of spatial association by use of distance statistics", Geographical Analysis, Vol. 24 No. 3, pp. 189-206.

Grinsted, A. and Christensen, J.H. (2021), "The transient sensitivity of sea level rise”, Ocean Science, Vol. 17 No. 1, pp. 181-186.

Hallegatte, S., Green, C., Nicholls, R.J. and Corfee-Morlot, J. (2013), "Future flood losses in major coastal cities", Nature Climate Change, Vol. 3 No. 9, pp. 802-806.

Hanson, S., Nicholls, R., Ranger, N., Hallegatte, S., Corfee-Morlot, J., Herweijer, C. and Chateau, J. (2011), "A global ranking of port cities with high exposure to climate extremes", Climatic Change, Vol. 104 No. 1, pp. 89-111.

Hinkel, J., Aerts, J.C., Brown, S., Jiménez, J.A., Lincke, D., Nicholls, R.J., Scussolini, P., Sanchez-Arcilla, A., Vafeidis, A. and Addo, K.A. (2018), "The ability of societies to adapt to twenty-first-century sea-level rise", Nature Climate Change, Vol. 8 No. 7, pp. 570-578.

Huang, X., Li, X., Wen, J., Li, W. and Du, S. (2017), "Measuring the economic losses and ripple effects of Shanghai automobile firms under extreme flood scenarios", Geographical Research, Vol. 36 No. 9, pp. 1801-1816.

Hunter, J.R., Church, J.A., White, N.J. and Zhang, X. (2013), "Towards a global regionally varying allowance for sea-level rise", Ocean Engineering, Vol. 71, pp. 17-27.

IPCC (2007), Climate Change 2007: The Physical Science Basis, Summary for Policymakers, Cambridge University Press, Cambridge.

Irish, J.L., Sleath, A., Cialone, M.A., Knutson, T.R. and Jensen, R.E. (2014), "Simulations of hurricane Katrina (2005) under sea level and climate conditions for 1900", Climatic Change, Vol. 122 No. 4, pp. 635-649.

Jiang, T., Zhao, J., Cao, L.G., Wang, Y.J., Su, B.D., Jing, C., Wang, R. and Gao, C. (2018), "Projection of national and provincial economy under the shared socioeconomic pathways in China", Climate Change Research, Vol. 14 No. 1, pp. 50-58.

Jongman, B. (2018), "Effective adaptation to rising flood risk", Nature Communication, Vol. 9 No. 1, p. 1986.

Jongman, B., Ward, P.J. and Aerts, J.C.J.H. (2012), "Global exposure to river and coastal flooding: long term trends and changes", Global Environmental Change, Vol. 22 No. 4, pp. 823-835.

Jonkman, S.N., Bockarjova, M., Kok, M. and Bernardini, P. (2008), "Integrated hydrodynamic and economic modelling of flood damage in The Netherlands", Ecological Economics, Vol. 66 No. 1, pp. $77-90$.

Jonkman, S.N. and Vrijling, J.K. (2008), "Loss of life due to floods", Journal of Flood Risk Management, Vol. 1 No. 1, pp. 43-56.

Kaplan, S. and Garrick, B. (1981), "On the quantitative definition of risk", Risk Analysis, Vol. 1 No. 1, pp. 11-27.

Ke, Q. (2014), Flood Risk Analysis for Metropolitan Areas: A Case Study for Shanghai, Delft, Delft University of Technolog.

Ke, Q., Jonkman, S., Van Gelder, P. and Bricker, J. (2018), "Frequency analysis of Storm-Surge-Induced flooding for the Huangpu river in shanghai, China", Journal of Marine Science and Engineering, Vol. 6 No. 2, p. 70.

Knutson, T.R., McBride, J.L., Chan, J., Emanuel, K., Holland, G., Landsea, C., Held, I., Kossin, J.P., Srivastava, A.K. and Sugi, M. (2010), "Tropical cyclones and climate change", Nature Geoscience, Vol. 3 No. 3, pp. 157-163.

Li, W., Wen, J., Xu, B., Li, X. and Du, S. (2019), "Integrated assessment of economic losses in manufacturing industry in Shanghai metropolitan area under an extreme storm flood scenario", Sustainability, Vol. 11 No. 1, p. 126. 
IJCCSM $13,4 / 5$

Li, W., Xu, B. and Wen, J. (2016), "Scenario-based community flood risk assessment: a case study of taining county town, Fujian province, China”, Natural Hazards, Vol. 82 No. 1, pp. 193-208.

Lin, N., Emanuel, K., Oppenheimer, M. and Vanmarcke, E. (2012), "Physically based assessment of hurricane surge threat under climate change", Nature Climate Change, Vol. 2 No. 6, pp. 462-467.

Lin, N., Kopp, R.E., Horton, B.P. and Donnelly, J.P. (2016), "Hurricane sandy's flood frequency increasing from year 1800 to 2100", Proceedings of the National Academy of Sciences, Vol. 113 No. 43, pp. 12071-12075.

Luu, C., Von Meding, J. and Kanjanabootra, S. (2017), "Analysing flood fatalities in Vietnam using national disaster database and tree-based methods", Natural Hazards and Earth System Sciences, Vol. 115.

Maaskant, B., Jonkman, S.N. and Bouwer, L.M. (2009), "Future risk of flooding: an analysis of changes in potential loss of life in South Holland (The Netherlands)", Environmental Science and Policy, Vol. 12 No. 2, pp. 157-169.

Marsooli, R. and Lin, N. (2020), "Impacts of climate change on hurricane flood hazards in Jamaica Bay, New York", Climatic Change, No. 20, pp. 1-19.

Merkens, J.L., Reimann, L., Hinkel, J. and Vafeidis, A.T. (2016), "Gridded population projections for the coastal zone under the shared socioeconomic pathways", Global and Planetary Change, Vol.145, pp. 57-66.

Merz, B., Kreibich, H., Schwarze, R. and Thieken, A. (2010), "Review article "assessment of economic flood damage\&quot", Natural Hazards and Earth System Sciences, Vol. 10 No. 8, pp. 1697-1724.

Micheal, O., Glavovic, B., Hinkel, J., Roderik, V, Magnan, A., Abd-Elgawad, A., Rongshu, C., Miguel, C.J., Robert, D., Ghosh, T., Hay, J., Ben, M., Meyssignac, B., Sebesvari, Z., A.J., S., Dangendorf, S. and Frederikse, T. (2019), "Sea level rise and implications for low lying islands, coasts and communities", in Pörtner, H.-O., Roberts, D. C., Masson-Delmotte, V., Zhai, P., Tignor, M., Poloczanska, E., K. Mintenbeck, Alegría, A., Nicolai, M., Okem, A., Petzold, J., Rama, B. and Weyer, N. M. (Eds) IPCC Special Report on the Ocean and Cryosphere in a Changing Climate, Cambridge University Press, Cambridge.

Nicholls, R.J., Hanson, S., Herweijer, C., Patmore, N., Hallegatte, S., Corfee-Morlot, J., Château, J. and Muir-Wood, R. (2008), "Ranking port cities with high exposure and vulnerability to climate extremes: Exposure estimates", OECD Environment Working Papers.

Paul, B.K. and Mahmood, S. (2016), "Selected physical parameters as determinants of flood fatalities in Bangladesh, 1972-2013”, Natural Hazards: Journal of the International Society for the Prevention and Mitigation of Natural Hazards, Vol. 83 No. 3, pp. 1703-1715.

Peduzzi, P., Chatenoux, B., Dao, H., Bono, A.D., Herold, C., Kossin, J., Mouton, F. and Nordbeck, O. (2012), "Global trends in tropical cyclone risk", Nature Climate Change, Vol. 2 No. 4, pp. 289-294.

Peduzzi, P., Dao, H., Herold, C. and Mouton, F. (2009), "Assessing global exposure and vulnerability towards natural hazards: the disaster risk index”, Natural Hazards and Earth System Sciences, Vol. 9 No. 4, pp. 1149-1159.

Promchote, P., Simon Wang, S.Y. and Johnson, P.G. (2016), “The 2011 great flood in Thailand: climate diagnostics and implications from climate change", Journal of Climate, Vol. 29 No. 1, pp. 367-379.

Qiang, Y. (2019), "Disparities of population exposed to flood hazards in the United States”, Journal of Environmental Management, Vol. 232, pp. 295-304.

Rahmstorf, S. (2017), "Rising hazard of storm-surge flooding", Proceedings of the National Academy of Sciences, Vol. 114 No. 45, pp. 11806-11808. 
Rasmussen, D.J., Bittermann, K., Buchanan, M.K., Kulp, S., Strauss, B.H., Kopp, R. and Oppenheimer, M. (2018), "Extreme sea level implications of $1.5^{\circ} \mathrm{C}, 2.0^{\circ} \mathrm{C}$, and $2.5^{\circ} \mathrm{C}$ temperature stabilization targets in the 21st and 22nd century", Environmental Research Letters, Vol. 13 No. 3, p. 34040.

Seto, K.C., Fragkias, M., Guneralp, B. and Reilly, M.K. (2011), “A meta-analysis of global urban land expansion", PLoS One, Vol. 6 No. 8, p. e23777.

Shan, X., Wen, J., Zhang, M., Wang, L., Ke, Q., Li, W., Du, S., Shi, Y., Chen, K., Liao, B., Li, X. and Xu, H. (2019), "Scenario-Based extreme flood risk of residential buildings and household properties in Shanghai”, Sustainability, Vol. 11 No. 11, p. 3202.

Sharif, H.O., Jackson, T.L., Hossain, M.M. and Zane, D. (2015), “Analysis of flood fatalities in Texas”, Natural Hazards Review, Vol. 16 No. 1, p. 4014016.

Tauzer, E., Borbor-Cordova, M.J., Mendoza, J., De La Cuadra, T., Cunalata, J. and Stewart-Ibarra, A.M. (2019), "A participatory community case study of periurban coastal flood vulnerability in Southern Ecuador”, PLoS One, Vol. 14 No. 10, p. e0224171.

Wang, J., Gao, W., Xu, S. and Yu, L. (2012), "Evaluation of the combined risk of sea level rise, land subsidence, and storm surges on the coastal areas of Shanghai, China", Climatic Change, Vol. 115 Nos 3/4, pp. 537-558.

Wang, J., Yi, S., Li, M., Wang, L. and Song, C. (2018), "Effects of sea level rise, land subsidence, bathymetric change and typhoon tracks on storm flooding in the coastal areas of Shanghai", Science of the Total Environment, Vol. 621, pp. 228-234.

Wang, L., Zhang, M., Wen, J., Chong, Z., Ye, Q. and Ke, Q. (2019), "Simulation of extreme compound coastal flooding in Shanghai", Advances in Water Science, Vol. 30 No. 4, pp. 546-555.

Ward, P.J., de Moel, H. and Aerts, J.C.J.H. (2011), "How are flood risk estimates affected by the choice of return-periods?", Natural Hazards and Earth System Sciences, Vol. 11 No. 12, pp. 3181-3195.

Ward, P.J., Jongman, B., Kummu, M., Dettinger, M., Sperna Weiland, F.C. and Winsemius, H.C. (2014), "Strong influence of El niño Southern oscillation on flood risk around the world", Proceedings of the National Academy of Sciences, Vol. 111 No. 44, pp. 15659-15664.

Webster, P., Holland, G., Curry, J. and Chang, H. (2005), "Changes in tropical cyclone number, duration, and intensity in a warming environment", Science, Vol. 309 No. 5742, pp. 1844-1846.

White, I., Connelly, A., Garvin, S., Lawson, N. and O'Hare, P. (2018), "Flood resilience technology in Europe: identifying barriers and co-producing best practice", Journal of Flood Risk Management, Vol. 11, pp. 468-478.

Winsemius, H.C., Van Beek, L.P.H., Jongman, B., Ward, P.J. and Bouwman, A. (2013), “A framework for global river flood risk assessments”, Hydrology and Earth System Sciences, Vol. 17 No. 5, pp. 1871-1892.

Wu, J., Li, Y., Li, N. and Shi, P. (2018), "Development of an asset value map for disaster risk assessment in China by spatial disaggregation using ancillary remote sensing data”, Risk Analysis, Vol. 38 No. 1, pp. 17-30.

Wu, S., Feng, A., Gao, J., Chen, M., Li, Y. and Wang, L. (2017), "Shortening the recurrence periods of extreme water levels under future sea-level rise", Stochastic Environmental Research and Risk Assessment, Vol. 31 No. 10, pp. 2573-2584.

Yin, J., Jonkman, S., Lin, N., Yu, D., Aerts, J., Wilby, R., Pan, M., Wood, E., Bricker, J., Ke, Q., Zeng, Z., Zhao, Q., Ge, J. and Wang, J. (2020), "Flood risks in sinking Delta cities: Time for a reevaluation?", Earth's Future, Vol. 8 No. 8, pp. e2020EF-001614.

Yin, J., Yin, Z., Yu, D. and Xu, S. (2012a), "Vulnerability analysis for storm induced flood: a case study of Huangpu river basin”, Scientia Geographica Sinica, Vol. 32 No. 9, pp. 1155-1160. 
IJCCSM

$13,4 / 5$

546
Yin, J., Yu, D., Yin, Z., Wang, J. and Xu, S. (2012b), "Multiple scenario analyses of huangpu river flooding using a 1D/2D coupled flood inundation model", Natural Hazards, Vol. 66 No. 2, pp. 577-589.

Yin, J., Yu, D., Yin, Z., Wang, J. and Xu, S. (2013), "Modelling the combined impacts of sea-level rise and land subsidence on storm tides induced flooding of the huangpu river in shanghai, China", Climatic Change, Vol. 119 Nos 3/4, pp. 919-932.

Yuan, Z. (1999), Flood and Drought Disasters in Shanghai, Hohai University Press, Nanjing, China.

\section{Corresponding author}

Weijiang Li can be contacted at: 1wj@shnu.edu.cn

For instructions on how to order reprints of this article, please visit our website: www.emeraldgrouppublishing.com/licensing/reprints.htm

Or contact us for further details: permissions@emeraldinsight.com 